We are called in, and find the patient has a quickened pulse, foul tongue, yellow coujuuctivæ, a dejected look, and he complains of feeling very low. Cross-questioning nearly always brings out the fact that at s'puer-time he had a gond meal, consisting of fi.h, flesh, or fowl. The most offending meat is pigs' $\mathrm{fl}$-sh in some form, chiefly as pork; then comes veal, and lastly plain beef or mutton. The fish most commonly giving rise to this sickners are salmon, mackerel, lobster, and crabs. A few cuses can be traced to high cheese or to eggs. Cucumber may help, especially if dressed in the usual way with salt and pepprr. But never have I seen a case where a purely vege. tar;an supuer has been takea. The treatment is very simple: allow spoun food every fuur or five hours, ic must not he not, but lukewarm ; euj iju rest, and give a mıld sedative of some kind. I am, Sir, your * truly,

Kingsland-road, E., Sept. 12th, 1882 . T. R. Allinson, L.R.C.P. Ed.

\section{VOLUNTEER AMBULANCE SERVICE.}

\section{To the Editor of THE LANCET.}

SIR, -As I have had numerous inquiries as to the formation and equipment of volunteer ambulance detachments, I sha!l feel obliyed by your insertion of the following particulars in your journal, for the information of those who have not already formed such detachments, and who are denirous of doing so.

The senior regimental surgeon, before instructing his class, should first make himself efficient by passing the Examination for Volunteer Medical Officers. The books required for this examination are : (1) "Parkes' Hygiene," by Professor De Chaumont; (2) "The Surgeon's Pocketbook," by Surgeon-Major Porter; (3) "Gunshot Injuries," by Professor Longmore; (4) "Manual of Instructions for Army Hospital Corps;" (5) "Manual of Exercise for Stretcher-bearers and Bearer Company ;" (6) "Army Medical Regulations."

As soon as the medical officer feels himself prepared for the examination he must apply, through his adjut $\star n t$, to the cunmanding officer of the reyiment to be examined. In due course he will receive an intimation from the principal medical officer of his head centre to appenr for examination. The examination is conducted by three officers of the Ariny Medical Department, is viva voce, thoroughly practical, and embraces the preventi,n and treatment of diseases peculiar to suldiers in camp anil on field service. The following are the wost imporant points :-(1) Sanitation of camp and precautions ayainst disease; (2) sanitation for troops on the line of march ; (3) geveral treatment of diseases common in camp and on field service; (4) first assistance to wounded on field of battle; (5) their removal and transport to field hospitals.

Un passiug this examination the medical officer will reseive a certificate of proficiency in the following words :"We certify that und $\mu \mathrm{r}$ the Medical Act of 1858 as qualified to practise medicine and surgery in Great Britain and Ireland), is well acquainted w1th the nature and intended application of the variou - articles composing the equipment of army hospitals in the field, and with the authorised means for the trans. port of sick and wounded soldiers, and the proper modes of employing them. We also certify that he has a competent knowledge of the treatment of the wounds and injuries to which troops are liahle in the field, particularly with regard to the special circumstances of campaigning; and that he is acquaiuted with the duties to be performed by army medical officers in camps and bivouacs, and during marches, as detailed in the Regulations for the Army Medical Deparment, Revised Arwy Regulations, vol. vi. Signatures of Board of Examining Otficers-. StationDate

I may bere mention that medical officers by thus obtaining this certificate of prufiviency will earn for their respective corus the special capitati $*$ allowance of $\mathrm{f2} 10 \mathrm{~s}$.

Assuming, then. that, the rnedieal officer has obtained his certiticate of proticiency, and wishes to form bearer detachments, his first duty, of course, is to obtain the permission of hiv commanding ufficer, then to select two men from each company in his battalion to be trained as stretcher-bearers.
Thirteen lec ures must be given of not less than an hour and a half's durarion each, at which each hearer must be present not leas than eleven times. The lectures are viven in ac cordance with the instructions issued by the Volunteer Am. bulance Department, a synopsis of which can be obtained by applying to Lient. Maclure, Volunteer Ambulance Department, Army Medical Denartment, 6, Whitehall - yard, Loudon, S.W., and from whom also can be obtained the stretchers and diaurams required. The field companion, haversack, and water-bottles are obtained from Messls, Savory and Moore, New Bond-street, London. As soon as the class has been duly trained the suryeon must apply to the principal medical officer of the district, who will cause the bearers to be examined, and if found proficient, will each receive a certificate on Army Form, E. 596. Two volunteers from each company who have so qualified will be selected by the commanding officer of the corps, on the recommendation of the medical officer, to be the stretcher bearers of the corps and to wear the Geneva Badge on their right arm. These badges can be obtained from Lieutenant Maclure also. I believe, as a rule, commded ng officers are glad to do all in their power to forward this movement, and $\widehat{I}$ can only speak of my own goud Colonel Sir William Worsley, Bt., and bis able adjutant, Major Hedley, as patterns in this respect.

I cannot conclude these few remarks without gratefully acknowleduing the great assistance and information received from Surgeon W. H. Platt, Treasurer, and Lieutenant Maclure, Secretary of the Volunteer Ambulance Department, when I was commencug this work myself,

I am, Sir, yours truly,

JOHN WM. TAYLOR, M.D., D.Śc, Surgeon 2nd Battalion North York Rifle Volunteers.

Scarborough, August 28ch, 1882.

\section{A CASE FOR HELP.}

To the Eclitor of THE LANCET.

SIR, - May we ask your readers to consider an appea? wh'ch we have to make on behalf of a medical man, late of Buntingford, Mr. Charles Gaffuey, who bas to be main. tained in an asylum by two sisters, who have much diff. culty in supporting themselves by a lodging-house in the Fulham-road. If some means of helping them is not quickly forthcoming, no alternative will remain but that of making him a panver luoatic. Their case is the haryer now as one of the sisters is ill with bronchitis, and their principal apartmen's are unoccupied. The merit of the case is further illustrated by the fact that two kind grants have been made by the British Medical Benevolent Fund--one of $£ 30$ in 1881 , and one of $£ 18$ in 1882 . The mental disease which has disabled Mr. Gaffuey has existed for nearly fifteen years. During part of this time he has been supported out of some means of his own, which tave lorg been entirely exhausted, and he is now dependent on two sisters, who are themselves very hardly pressed and confronted with the workhouse. A few kindly subsciptions at this adverse moment might help two good sisters to keep an insane brother, and brighten what seems a very dark look-out. We are, Sir, your obedient servants, A. P. STEWART, M.D.

Subscriptions already received :J. G. GLOVER, M. D.

$\begin{array}{lllllllll}\text { THE LANCET } & \ldots & \ldots & \ldots & \ldots & \ldots & £ 2 & 2 & 0 \\ \text { Dr. Stewart } & \ldots & \ldots & \ldots & \ldots & \ldots & 2 & 2 & 0 \\ \text { Dr. Glover } & \ldots & \ldots & \ldots & \ldots & \ldots & 2 & 2 & 0\end{array}$

\section{HOMES FOR INEBRIATES.} To the Editor of THE LANCET.

SiR,-In his second annual report the able Inspector of Inebriate Retreats strongly urges the need for the opening of the proposed Dalrymple Home for Inebriates. Though indefatigable in their efforts, the committee have received very limited pecuniary support. They, however, hope to be able to commence operations before the end of this year. The triumphant progress of temperance missions is daily recorded by the Press, and it is to be hoped that the unse'fishness and devotion which ought to he the motive power of such a crusade will be attested by liberal financial support to the projected Dalrymple Home as an attempt âे 
the refirwarion aud cure of the many habitual drunkards whose whole system has become so diseased by alcohol that absolute seclusion from temptation is essential to restore their shartered nerves and their utterly broken down will power. Among the office bearers of the proposed Home are the Archbishop of Canterbury, the Duke of Westminster, Lord Shaftesbury, Sir Thos. Watson, Sir Henry Thompzon, Dr. Andrew Cldrk, and Dr. B. W. Richardson. £3000 is still needer. Dinations and also annual subscriptions will be thankfully received by the chairman, Canon Duckworth, Dr. Alfred Carpenter, J.P., Croydon.

I am, Sir, your obedient servant,

NORMAN KFRR, M.D., Hon. Sec., Dalrymple Home.

Grove-road, Regent's-park, N.W., September 9th, 1882.

\section{CLINICAL THERMOMETRY.}

\section{To the Editor of THE LANCET.}

SIR, -I wish to call your attention to a possible source of error in clinical thermometry. I have one of Maw's seveninch hospital thermometers, and I accidentally discovered that by grentle esmpression of the mercurial bulb I was enabled to make the index rise some three or more deyrees; such pressure the bulb might easily be subject to in the axillary space, especially if the arm be pressed close to the side. I am, Sir, yours traly,

$$
\text { Brighton, Sept. 5th, 1882. J. M. E. SCATLIFF, M.D. }
$$

\section{NERVE-VIBRATION : A CAUTION. To the Editor of THE LANCET.}

CSIR,-Will you permit me as the originator of the method of "Nerve-vibration by precise percussion" in the treatment of certain forms of nervous disease and disturbance to warn the profession against the conversion of this method into a "cure" or "system"-of which we have already too many misehievous specimens-by placing my percuteurs in the hands of patients and their friends. As well, and more safely, might toose gentlemen who are pursuing this course supply their clieuts with scalpels, galvanism, electricity in its various developments, and hypodermic injections, which have been reduced to the level of nostrums by this reckless procedure.

I must earnestly protest against the abuse of nerve-vibration by a like policy. My protest is made not less in the interests of the sufferers from diseases than in that of professional propriety. Nerve-vibration is a potent agency for good or evil, as it happens to be applied. It is exceedingly difficult of application, and reauires to be employed with the greatest care and intelligence. A thorough knowledge of the anatomy and physiology of the nervous system is indispensable for its safe and successful use. If medical men have not the time or do not care to administer it themselves, they will do wisely to leave it alone.

Already I have seen harm ensue from its misuse, and I therefure feel bouad to give this warning to medical men who having heard of cases which have been benefited are purchasing or borrowing instruments for their patients to use! Nothing but disappointment can result from this indiscretion.

I am, Sir, yours truly,

Welbeck-street, W., Sept. 1882. J. MorTMMER GRANVILLE.

\section{GLASGOW.}

(From our own Correspondent.)

$\operatorname{Mr}$, GEo. A. D. MACKAY read an interesting paper at the recent annual.meeting of the Sanitary Association of Scotland, in which he reviewed the improvement which had been effected in the public health in Greenock since the local authority had obtined special Parliamentary powers. Before 1876 the general mortality of the town was higher than in any other town in Scotland; while the special mortality in certain of the closes and blocks of buildings was appulling- 40 to 67 per 1000 of the porpulation on an average of ten years. The removals to the hospital and fever-house were so numerous that they were equivalent to the whule population of the locility heing sent there in the space of twenty-five years. The mean annual death-rate during the periud $1875-75$ was $31 \cdot 24$ per 1000 ; whlle in the five years $1876-80$ it was 24 per 1000 , and last year $22 \cdot 14$. Contrusting the mortalities of these neriods, this improvement is equal to 621 lives saved. This change bas taken place notwithstanding the many physical drawbacks from which Greenock suffers-a bad site, a proverbially rainy climate, irregular and narrow streets, extreme coicentration of population, and a smoky atmosphere. The figures $\mathbf{I}$ have quoted are excellent, and show that the Greenock authorities have not fallen behind in the march of sanitary progress.

The position of surgeon to laroe industrial establishments is becoming anything but an envable one in this part of the country. This is in part due to the assertion by the workmen, ia many quarters, of their right to elect their medical officer themselves, in consideration of the fact that $h\lrcorner$ is paid by sums retained periodically from their wages; power is thus transferred from the masters to the men, a chinge which does not seem to have a very elevating inflnence on the tactics adopted by contending medical candidates in many instances. For example, we have at present a contest going on in Glasgow for the surgeonship to certain ironworks, a place of some pecuniary value, for which about forty applicants are striving, some of them after a fashion hitherto supposed to bulong exclusively to parliamentary or municipal elections; thus, the works are placarded with bills advising the men to "Vote for ___!" ; and handbulls are circulated asking "Why vote for cause he is a gentleman; because you all know him" and so on. It is to be hoped that it is the injudicisus frieuds of the candidares, and not the candidates themrelves, who are at the bottom of all this.

Sounds of preparation for the coming winter are heard in all our numerous local medical suhools. At the University there is no change of any importance to chronicle. At the Royal Infirmary the managers have shown by their laudable energy and liberality that they have the good of their medical school at heart, the new block of buildings which has been erected, to be devoted entirely to the vurposes of the school, providing almost a sup rabuadance of accommodation for the lecturer. Such enterprise indicates faith in their future. The staff of the Western Medical Sethool has been increased by the appointment of Mr. W. Limınt as lecturer on Physiology. At Anderson's College things remain pretty much as they were last year. The calendar just issued by this college is, in a certain sense, very instructive reading. The interest lies, as usual, in the statistics. On looking at the statement of the number of studeats in attendanse last year, winter and sum'ser, it is found that the grand total amounts to 2405. These fiyures are startling, and to the uninitiated give the impression of a very extensive concern. Even after deductiug nearly 900 , the number attending the popular evening classes, and about 1100 , the number said to attead the non-medical classes, we have a medical school with an alleged strength of over 400 , a siatement which we in Glazoow know to be ntter nonsunse. And the manner in which this result is achieved is delishtfully simple; it is the old trick ( $f, r$ it is nothing els:) so $f$ amiliar to cuuntry theatrical manayers who have to make a handful of "supers" do duty for the British Armv by effecting numerous entries and exits; each student is reckuned in once for every class he attends, both summer and winter. A studeut, therefore, who takes, say four clisses in winter and two in summer, fiads that he plays rather an important part in these statistics. This ready method of " maynifying one's office" is really a credit to the author.

There was another unfortunate death from chloroform in the Royal Infirmary the other day. The op:ration fur which it was given was, as is mo it commıniy the case, a very trifling one, the removal of some smushed toes. Doultiess $a^{*}$ report of the case will be forthcomm.g.

The salary of Dr. Jimes B. Russeli, melical officer for the city, has been raised from $£ 700$ to $£ \$ 50$ per annum, and is thus brought more into aceord with the many a.d im portant duties of the office and tie services Dr. Russell has already rendered to the city.

It is freely reported both here and in Aberdeen that Dr. William M'E wen of this city is standing as a castidate for the vacant chair of survery iu Aberieen University. I believe I am right, however, in styung that Dr. $M^{\prime} \mathrm{Ew}-\mathrm{n}$ has given up all intention of joiniug in the contest. Pussi.ly the loss of hospital practice which such an appoiutment 